\title{
The effects of topical liposomal resveratrol on incisional and excisional wound healing process
}

๑ Mehmet Yalçın Günal, ๑ Șule Ayla*, ๑ Nejda Bedri*, ๑ Mustafa Çağlar Beker**, ๑ Ahmet Burak Çağlayan**, ๑ İsmail Aslan***, ๑ Ekrem Musa Özdemir**, ๑ Erdem Yeșilada****, ๑ Ülkan Kılıç*****

\author{
Alanya Alaaddin Keykubat University Faculty of Medicine, Department of Physiology, Antalya, Turkey \\ *istanbul Medipol University Faculty of Medicine, Department of Histology-Embryology, Istanbul, Turkey \\ **istanbul Medipol University, Regenerative and Restorative Medical Research Center (REMER), Istanbul, Turkey \\ ***University of Health Sciences Faculty of Pharmacy, Istanbul, Turkey \\ ****Yeditepe University Faculty of Pharmacy, Department of Pharmacognosy, Istanbul, Turkey \\ *****University of Health Sciences Faculty of Medicine, Department of Medical Biology, İstanbul, Turkey
}

\begin{abstract}
Background and Design: The objective of this study was to investigate the wound healing activity of different concentrations of liposomal trans-resveratrol formulations on incisional and excisional wounds in rats.

Materials and Methods: The wound healing effect was tested by an excisional and incisional wound model. Wound closure was measured for 12 days. On the $12^{\text {th }}$ day of the study, maximal load, maximum stress, stress, and $\%$ of elongation values were evaluated in the incisional wound. In addition, angiogenesis, granulation tissue thickness, epidermal and dermal regeneration values, and macroscopic photographic analyses were evaluated in the excisional wound.

Results: When the wound tissue surface healing rates were evaluated, similar effects were observed at the end of the $10^{\text {th }}$ and $12^{\text {th }}$ days between the 5\% Res group and the commercial product containing 1\% Centella asiatica extract used as the reference molecule. Histological evaluation showed that $1 \%$ Res and $5 \%$ Res groups induced significant wound healing activity compared to the control group. Furthermore, $1 \%$ Res and $5 \%$ Res groups increased wound healing rates by promoting granulation tissue, epidermal, and dermal regeneration as well as angiogenesis.

Conclusion: Liposomal formulations containing $1 \%$ and $5 \%$ resveratrol were found to have positive effects on the healing process, both on excisional and incisional wound tissues.

Keywords: Resveratol, liposome, incisional wound, excisional wound, axial tensile-elongation tests

Öz

Amaç: Bu çalışmanın amacı, sıçanlarda insizyonel ve eksizyonel yaralar üzerine farklı konsantrasyonlarda hazırlanmış lipozomal trans-resveratrol formülasyonlarının yara iyileşme aktivitesi üzerine etkinlï̆ini araştırmaktır.

Gereç ve Yöntem: Yara iyileşme etkisi, eksizyonel ve insizyonel yara modeli kullanılarak test edildi. Yara yüzey alanları 12 gün süresince ölçüldü. Çalışmanın 12. gününde, insizyonel yaralarda maksimum yük, maksimum stres, gerginlik (strain) ve \% uzama değerleri değerlendirildi. Ek olarak, eksizyonel yaralarda anjiyogenez, granülasyon dokusu kalınlığı, epidermal ve dermal rejenerasyon değerleri ve makroskopik fotoğraf analizleri değerlendirildi.
\end{abstract}

Address for Correspondence/Yazışma Adresi: Mehmet Yalçın Günal MD, Alanya Alaaddin Keykubat University Faculty of Medicine, Department of Physiology, Antalya, Turkey

Phone: +90 5325577356 E-mail: yalcin.gunal@alanya.edu.tr Received/Geliş Tarihi: 05.08.2018 Accepted/Kabul Tarihi: 02.03.2019 ORCID: orcid.org/0000-0001-7702-2441

(C) Copyright 2019 by Turkish Society of Dermatology and Venereology

Turkderm-Turkish Archives of Dermatology and Venereology published by Galenos Yayınevi. 
Bulgular: Yara dokusu yüzey iyileşme oranları değerlendirildiğinde, \%5 Res grubu ile referans molekül olarak kullanılan 1\% Centella asiatica ekstresi arasında 10. ve 12. günlerde benzer etkiler gözlendi. Histolojik değerlendirme, \%1 Res ve \%5 Res gruplarının kontrol grubuna kıyasla anlamlı yara iyileşme aktivitesi oluşturduğunu gösterdi. Ayrıca, \%1 Res ve \%5 Res grupları, granülasyon dokusu, epidermal ve dermal rejenerasyonun yanı sıra anjiyogenezi uyararak yara iyileşme oranlarını arttırdı. Sonuç: \%1 ve \%5 resveratrol içeren lipozomal formülasyonların, hem eksizyonel hem de insizyonel yara dokularında iyileşme süreci üzerinde olumlu etkileri olduğu bulunmuştur.

Anahtar Kelimeler: Resveratol, lipozom, insizyonal yara, eksizyonal yara, eksenel çekme-uzama testleri

\section{Introduction}

When the skin tissue is damaged, the body responds quickly with functional regeneration, which is called wound healing. The wound healing process has 5 important steps, homeostasis and inflammation, granulation tissue formation, neovascularization, reepithelialization, and remodeling ${ }^{1}$. Numerous molecules that act on this process at different stages have been used in research to accelerate or regulate wound healing ${ }^{2}$. Resveratrol is one of these molecules. Resveratrol (3,5,40-trihydroxy-trans-stilbene) is abundant in Polygonum cuspidatum roots, grapes, peanuts, plums, strawberries and red wine ${ }^{3}$. Previous studies have shown that resveratrol has anti-inflammatory, immunomodulatory, cardioprotective, antidiabetic, neuroprotective, hepatoprotective and antioxidant properties ${ }^{47}$. In rodent models, resveratrol has been shown to inhibit lipopolysaccharide-induced acute lung inflammation by inhibiting TLR4/NF-кBp65/MAPKs signaling cascade and NLRP3 inflammatory markers ${ }^{8,9}$. Reactive oxygen species (ROS) are natural byproducts of cellular metabolism and cause cell death at extreme levels ${ }^{10}$. SIRT1 reduces ROS levels and enhances cell activity ${ }^{11}$. Resveratrol increases SIRT1 in human pulmonary alveolar epithelial cells, reduces ROS production, protects cell membrane potential, and prevents apoptosis in alveolar epithelial cells, thereby reducing hyperoxia-associated lung damage ${ }^{12}$. The antioxidant properties of resveratrol are not limited to the lungs alone. It has been shown in experimental studies that rats are protected against ischemiareperfusion injury in the heart ${ }^{13}$. In a number of studies resveratrol has been shown to be effective at different doses for skin cancer ${ }^{14}$, breast cancer ${ }^{15}$, prostate cancer ${ }^{16}$, lung cancer ${ }^{17}$, colon cancer $^{18}$ and liver cancer ${ }^{19}$.

Yaman et al..$^{20}$ investigated the incisional wound healing process in rats given oral resveratrol in their research in 2013 and concluded that oral resveratrol was effective. Another study by Tang et al. ${ }^{21}$ showed that resveratrol inhibits the formation of pathological scar tissue and inhibits fibroblast proliferation by decreasing mTOR and 7056K expression. Increasing the absorption of a molecule into the target tissue by adding it into liposomes is often preferred recently. One of the most important advantages of using liposomes is that liposomes can be prepared in desired sizes and thus pass through regions such as the blood-brain barrier where the molecules they carry do not normally pass through. For example, the study of Ethemoglu et al. ${ }^{22}$ investigated the effect of trans-resveratrol loaded in liposomes on penicillin-induced epileptic activity model. When trans-resveratrol is used orally, its effectiveness is limited due to low water solubility, stability, and low bioavailability 23,24 . Nanoencapsulation has proven that molecules are effective in increasing water solubility, chemical stability, and bioavailability of bioactive compounds ${ }^{25}$. The use of liposomes as a drug carrier allows the drug to reach adequate penetration and concentration in the target tissue and reduce systemic side effects to a minimum ${ }^{26}$. Liposomes are potentially beneficial vehicles for the topical delivery of active pharmaceutical ingredients. There is no singificant changing on skin strucure in previous study of empty liposomes ${ }^{27}$. Three dimensional images of volunteers skin was evaluaeted 2 weeks before-after study. According to results active ingredient (sodium hyaluronate) containing liposomes have significant effect on wrinkles and integration of skin structure. However, empty liposomes have no important differentiation effect of skin structure ${ }^{28}$. In another reseach, wound reepithelialization was measured by computerized planimetry as percentage original wound area, it was significantly increased wound reepithelialization rats receiving active ingredient insulin-like growth factor-I (IGF-I) containing liposomes when compared to sham, or IGF-I $(p<0.05)$. Sham formulations have neglicible effect on wound reepithelialization ${ }^{29,30}$.

Centella asiatica extract (CAE) is a molecule that facilitates the repair process of the wound tissue and has been shown to exhibit antimicrobial activity ${ }^{31}$. For this reason, it has been preferred as a reference molecule in many studies including our study.

In many previous studies, the tensile strength was measured to determine the amount of improvement in the skin tissue in incisional wound healing ${ }^{32}$. In addition to the parameters examined in previous studies, we aimed to obtain more data by measuring the parameters of maximum load, stress, strain, and elongation on the healing of incisional wound tissue in our study. Maximum load expresses the maximum strength after the maximum tensile force applied to the skin tissue sample. The pulling force applied to the skin tissue prolongs the skin tissue sample. When the maximum load value is reached, the tissue starts tearing. Stress (Mpa) is defined as the amount of force acting on the unit area. It is caused by applying a force perpendicular to the surface area to extend the skin sample in the direction of the pulling force and is also called tensile stress. Strain $(\mathrm{mm} / \mathrm{mm})$ refers to the extent to which the skin sample under load changes its shape compared to the condition before the load is applied. This definition is a concept that allows the mathematical expression of the deformation of materials with elastic properties. Elongation refers to the \% change of the difference between the length of the skin tissue before starting the tensile test and the length of the skin immediately preceding the break.

This study aimed to investigate the effect of resveratrol loaded in liposomes on incisional and excisional wound tissue topically.

\section{Materials and Methods}

\section{Animals}

Male Wistar-Albino rats weighing 250-300 gr were used in the study. The rats were hosted in regular cages with food and water ad libitum, at room temperature $\left(24^{\circ} \mathrm{C}\right)$ with artificial light from 7.00 am to 7.00 pm. Before performing in vivo experiments, ethical clearance approval 
was obtained from the Local Ethical Committee (İstanbul Medipol University, Turkey, (approval number: 44, date: 07.08.2018). Informed consent is not necessary as it is an animal experiment. The experimental animals were divided into 4 groups of 8 animals per group, control, commercial product containing 1\% CAE, group of containing $1 \%$ resveratrol ( $1 \%$ Res) and group of containing $5 \%$ resveratrol (5\% Res).

\section{Preparation of liposome formulations containing trans-resveratrol}

The chemicals used to prepare the liposome formulations were supplied from the relevant companies [hydrogenated phosphatidylcholine, LIPOID GmbH, Germany, Dicetyl phosphate, Sigma Aldrich, United States of America (USA), Cholesterol, Fluka Research Chemicals, USA)]. Liposomal dispersion formulation was prepared by thin film technique. Briefly, liposome was prepared by dissolving the $100 \mu \mathrm{M}$ of phospholipids and lipophilic active substance (trans-resveratrol, Interpharma, Chezc Republic) in $30 \mathrm{~mL}$ chloroform-methanol mixture in a round-bottom flask. The organic solvents were removed using a rotary evaporator under reduced nitrogen pressure to form a thin film over the wall of round-bottom flask. The dried film was then hydrated over a water bath with $10 \mathrm{mM}$ Tris Buffer pH 5.5 above phase transition temperature. After multi lamellar vesicle preparation, sonication process and incorporation technique were applied, respectively. Final transresveratrol concentrations were $1 \%(\mathrm{w} / \mathrm{v})$ and $5 \%(\mathrm{w} / \mathrm{v})$, respectively (Table 1). Then liposomes were sonicated during 5 minutes $\times 3$ times to provide content uniformity. All dispersions were kept at $4{ }^{\circ} \mathrm{C}$ until usage under nitrogen.

Once the liposomes were prepared, their sizes, zeta potentials and Poly Dispersity Index (PDI) values were measured (Table 2). According to the results obtained, the mean particle size distribution of empty liposomes is lower than that of resveratrol loaded liposomes because trans-resveratrol is encapsulated. Compared to empty liposomes, those

\begin{tabular}{|l|l|l|l|l|}
\hline \multicolumn{5}{|c|}{ Table 1. Liposome formulation and composition } \\
\hline Code & Composition & pH & $\begin{array}{l}\text { Molar } \\
\text { ratio }\end{array}$ & Observations \\
\hline $\mathbf{1 \%}$ Res & $\begin{array}{l}\text { *HPC:DCP: } \mathrm{CHOL+} \\
\text { resveratrol }(1 \% \mathrm{w} / \mathrm{v})\end{array}$ & 5.5 & $10: 1: 4$ & Milky dispersion \\
\hline $\mathbf{5 \%}$ Res & $\begin{array}{l}\mathrm{HPC}: \mathrm{DCP}: \mathrm{CHOL+} \\
\text { resveratrol }(5 \% \mathrm{w} / \mathrm{v})\end{array}$ & 5.5 & $10: 1: 4$ & Milky dispersion \\
\hline $\begin{array}{l}\text { *HPC: Hydrogenated phosphatidyl choline, DCP: Dicetyl phosphate, CHOL: } \\
\text { Cholesterol }\end{array}$
\end{tabular}

\begin{tabular}{|c|c|c|c|c|}
\hline Code & Composition & Size (nm) & $\begin{array}{l}\text { Zeta } \\
\text { Potential } \\
(\mathrm{mV})\end{array}$ & PDI \\
\hline $\begin{array}{l}\text { Res } \\
\text { Free }\end{array}$ & $\begin{array}{l}{ }^{*} \mathrm{HPC}: \mathrm{DCP}: \mathrm{CHOL} \\
\text { (resveratrol free) }\end{array}$ & $134.20 \pm 4.38$ & $-22.4 \pm 0.12$ & $0.112 \pm 0.002$ \\
\hline $\begin{array}{l}1 \% \\
\text { Res }\end{array}$ & $\begin{array}{l}\mathrm{HPC}: \mathrm{DCP}: \mathrm{CHOL}+ \\
\text { resveratrol }(1 \% \mathrm{w} / \mathrm{v})\end{array}$ & $168.80 \pm 8.20$ & $-26.8 \pm 0.26$ & $0.146 \pm 0.001$ \\
\hline $\begin{array}{l}5 \% \\
\text { Res }\end{array}$ & $\begin{array}{l}\mathrm{HPC}: \mathrm{DCP}: \mathrm{CHOL}+ \\
\text { resveratrol }(5 \% \mathrm{w} / \mathrm{v})\end{array}$ & $192.20 \pm 8.44$ & $-27.2 \pm 0.82$ & $0.175 \pm 0.004$ \\
\hline
\end{tabular}

with resveratrol are larger. Liposomes can penetrate into the skin up to $600 \mathrm{~nm}$ in diameter, but can not penetrate to the skin tissue if they are as large as $1000 \mathrm{~nm}^{33,34}$. According to our results, liposomes containing $1 \% \operatorname{Res}(168.80 \mathrm{~nm} \pm 8.20)$ and liposomes containing 5\% Res (192.20 $\mathrm{nm} \pm 8.44$ ) can easily pass through skin tissue (Table 2). $1 \%$ and $5 \%$ resveratrol formulations were optimized based on their PDI and Zeta potential values. The Zeta potential is a function of the general charge of a particle. Changes in particle size give information about aggregation and fusion events. Stability increases if the Zeta potential rises above-25 $\mathrm{mV}$ and $+25 \mathrm{mV}$ (away from zero). As this potential value approaches zero, the product loaded with liposomes breaks down quickly. In our study, $-26.8 \mathrm{mV}$ for $1 \%$ resveratrol and $27.2 \mathrm{mV}$ for $5 \%$ resveratrol were found for optimum liposome formulations with Zeta potential. Therefore, it is seen that the liposomes we have used have a stable structure. The value of PDI is an indication of the rate of degradation of liposomes. As the PDI value increases, the rate of degradation of the liposome increases ${ }^{35}$. When we evaluated liposomes from the point of view of PDI, resveratrol-loaded liposomes had a larger particle size than empty liposomes, and PDI values were between 0.1 and 0.5 , which is the ideal value. According to all these data, liposomes containing $5 \%$ Res may be preferred because they have a larger diameter than liposomes containing 1\% Res, 5 times more active ingredient and higher Zeta potentials.

\section{Anesthesia and wound creation protocols}

Rats were anesthetized with a combination of $60 \mathrm{mg} / \mathrm{kg}$ ketamine and $6 \mathrm{mg} / \mathrm{kg}$ xylazine intraperitoneally ${ }^{36}$. The back area was shaved and the area was cleaned with $70 \%$ alcohol. The modified wound model was used to create the wound model considering the information in the literature ${ }^{20,36,37}$. Two excisional wound tissues were formed using a $5 \mathrm{~mm}$ punch biopsy instrument on the left side of the midline in the shaved back region, one $\mathrm{cm}$ apart from each other and $1.5 \mathrm{~cm}$ away from the midline. Except for the control group, Linear fullthickness incisional wound was formed in a length of $2 \mathrm{~cm}$ using a No. 11 surgical scalpel to remain $1.5 \mathrm{~cm}$ to the right of the midline in the dorsal region. Incisional wound edges were sutured using 3/0 silk thread. In the control group, only the excisional wound model was formed as described above. Drug formulations and CAE were administered topically to the relevant groups at 10.00 am every day for 11 days. On day 12 of the study, the rats were sacrificed under anesthesia, tissue samples were taken for histological evaluation and wound tension measurement.

\section{Macroscopic evaluation}

From the day when the excisional wound tissue was formed, the every other day photographs were taken and the surface areas were measured with the ImageJ program. Afterwards, wound healing rates were calculated by the formula given in the literature 36,38 .

\section{Histological evaluation}

On day 12, the animals were sacrificed by decapitation and the skin of the back including the wound area was removed. Full-thickness biopsy samples extended from the outside margin to the center of the treated area. All tissue specimens were fixed in 10\% neutral formalin for at least $25 \mathrm{~h}$ at room temperature. After fixation, wound samples were dehydrated in graded ethanol series, cleared in xylene and embedded in paraffin. $5 \mu \mathrm{m}$ thick sections (Thermo Microm HM 340E, 
Waltham, US) were mounted on glass slides, dewaxed, rehydrated with distilled water and stained with hematoxylin-eosin according to routine procedures for light microscopy. The images were taken under a Nikon Eclipse Ni (Nikon Instruments Europe BV, Amsterdam, Holland) research microscope. Measurement was performed by two independent researchers blind to the drug administration groups. Wound healing for each group was evaluated via use of the scoring system previously described by Galeano et al. ${ }^{39}$ for epidermal and dermal regeneration as: score 1 for poor epidermal organization in $\geq 60 \%$ of the tissue, score 2 for incomplete epidermal organization in $\geq 40 \%$ of the tissue, score 3 for moderate epithelial proliferation in $\geq 60 \%$ of the tissue and score 4 for complete epidermal remodeling in $\geq 80 \%$ of the tissue. For thickness of the granulation tissue, scoring was: 1 for thin granulation layer, 2 for moderate granulation layer, 3 for thick granulation layer, 4 for very thick granulation layer. For angiogenesis, only mature vessels were counted and identified by the presence of erythrocytes in the lumen. To distinguish well formed capillaries from poorly formed ones, we evaluated the presence or absence of edema, congestion, hemorrhage, thrombosis and intravascular or intervascular fibrin formation. Score 1 describes altered angiogenesis (one to two vessels/site) characterized by high degree of edema, hemorrhage, occasional congestion and thrombosis, score 2 describes few newly formed capillary vessels (3-4/site), moderate edema and hemorrhage, occasional congestion, intravascular fibrin deposition and absence of thrombosis, score 3 describes newly formed capillary vessels (5-6/site) and score 4 describes newly formed and normal appearing capillary vessels (>7/site) $)^{39-41}$.

\section{Wound tension measurements in incisional wound tissue (axial tensile-elongation experiments)}

Axial tensile-elongation experiments were carried out on a TA Instruments QA-800 mechanical analyzer at Yeditepe University Engineering Faculty. In order to standardize the data obtained from the skin samples taken after the incisional wound model, the crosssectional areas of skin tissues to be subjected to tensile-elongation tests were measured separately. During the measurement, the skin tissues were attached to the fixed ends of the mechanical analyzer. All pull tests were initiated by resetting the force sensor. At certain intervals, a draw of 100 microns was applied. At the same time, the device continued to record by continuously measuring the stress-strain responses with applied force. Maximum load, maximum stress, strain and percent elongation values calculated in skin tissue.

\section{Statistical Analysis}

For statistical data comparisons, a standard software package (SPSS 20 for Windows, SPSS Inc., Chicago, IL, USA) was used. Differences between groups were analyzed by one-way ANOVA, followed by least significant differences tests. All values were given as mean \pm S.E.M. P values $<0.05$ were considered significant.

\section{Results}

- There was no significant difference between the groups when compared with the control group at $2^{\text {nd }}$ and $8^{\text {th }}$ days in the evaluation of the surface of the excisional wound. However, there was a significant difference on the $4^{\text {th }}$ day, between CAE and the control group ( $p=0.048$ ), on the $6^{\text {th }}$ day, between the control group and $1 \%$
Res $(p=0.005)$ and $5 \%$ Res $(p=0.004)$ groups, on the $10^{\text {th }}$ day, between the control group and CAE ( $p=0.01), 1 \%$ Res $(p=0.026)$ and $5 \%$ Res $(p=0.000)$ groups, on the $12^{\text {th }}$ day between the control group and CAE $(p=0.037)$ and $5 \% \operatorname{Res}(p=0.003)$ groups (Figure 1).

- In the histological scoring of the healing of the excisional wound tissue, epidermal and dermal regeneration, granulation tissue formation and angiogenesis were better in the $1 \%(p=0.697)$ and $5 \%$ resveratrol $(p=0.245)$ groups than in the control group, but not statistically significant (Figure 2).

- When the maximum load, maximum stress, strain and \% elongation values of the incisional wound were evaluated, there was a significant decrease in all groups compared to the control group. On the other hand, no significant difference was found between the other groups compared with the control group. In particular, the group containing $5 \%$ Res compared to CAE, the preferred reference molecule for wound healing, was almost identical (Figure 3). There was no statistically significant difference between the other groups except for the control group.

\section{Discussion}

The wound healing process includes stages such as inflammation, cellular proliferation and remodeling, and cell-cell and cell-matrix interactions during these stages ${ }^{1}$. Numerous studies have shown that essential oils of various medicinal plants increase the wound healing with active ingredients from aromatic plants and fruits ${ }^{2}$. Resveratrol is a molecule with anti-inflammatory, immunomodulator, cardioprotective, antidiabetic, neuroprotective, hepatoprotective, antioxidant and

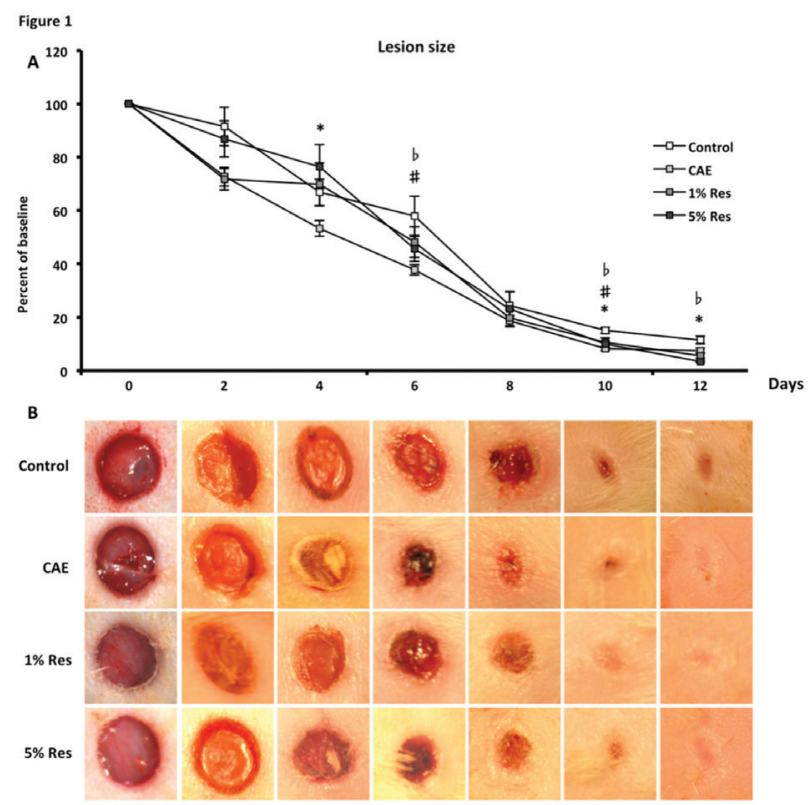

Figure 1. The effect of resveratrol on wound healing process in the excisional wound model. A) Healing percentage of wound tissue surface area in each group. ${ }^{*} \mathrm{P}<0.05$ control group compared with commercial product containing 1\% Centella asiatica extract, ${ }^{*} p<0.05$ control group compared with $5 \%$ Res, ${ }^{b} p<0.05$ control group compared with $1 \%$ Res. All values are given as mean \pm S.E.M. B) Macroscopic photographs of wound tissue CAE: Centella asiatica extract 

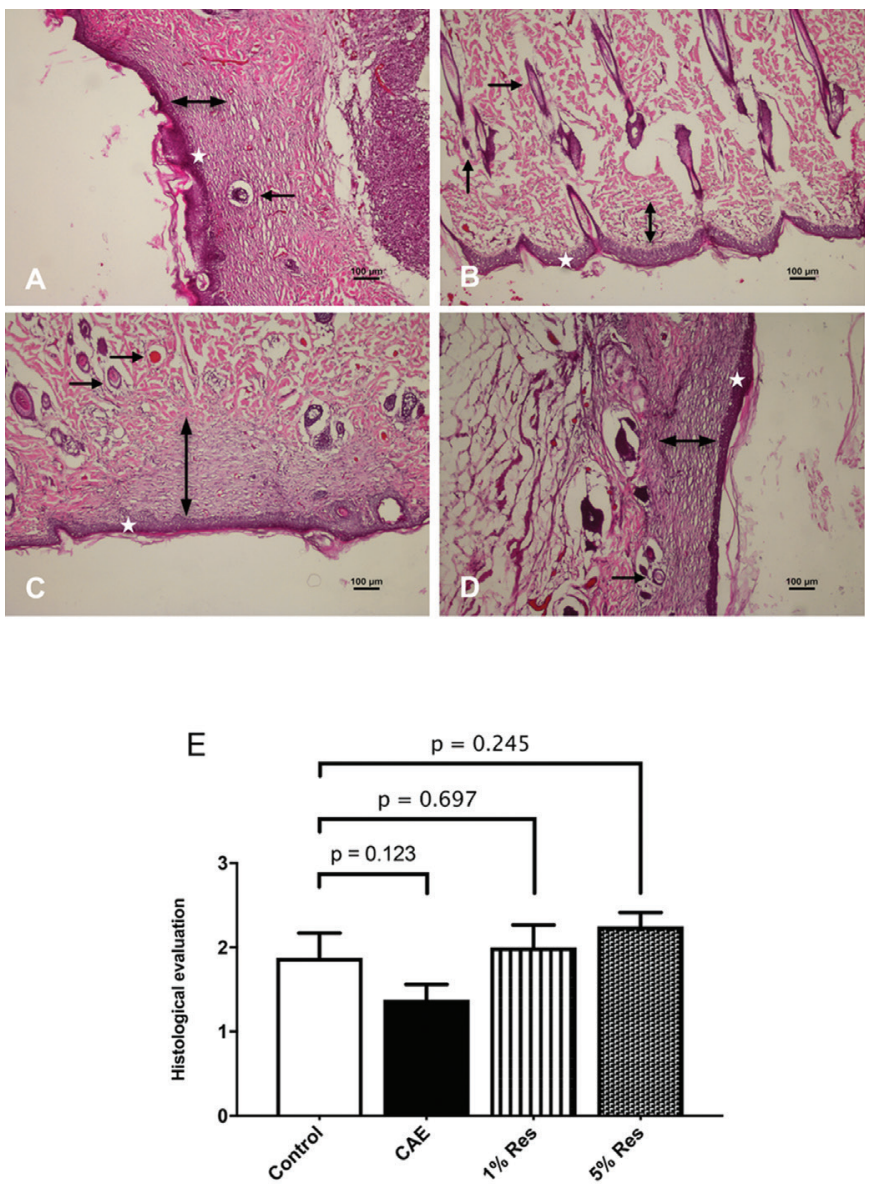

Figure 2. Histological evaluation of wound tissue [hemotoxylen and eosin (H\&E), (original magnification $\times 10)$ ]. The scale bars represent $100 \mu \mathrm{m}$ for a figure. A) Control group, B) Centella asiatica extract group, C) $1 \%$ Res group, D) $5 \%$ Res group, E) histological scoring of wound tissues. In the histological scoring of the healing of the excisional wound tissue, epidermal regeneration (it is illustrated by " $\star$ " in the figure), dermal regeneration and granulation tissue (it is illustrated by " $\leftrightarrow$ " in the figure), and angiogenesis (it is illustrated by " $\rightarrow$ " in the figure) were better in the $1 \%$ and $5 \%$ resveratrol groups than in the control group, but not statistically significant CAE: Centella asiatica extract

anticancer properties, especially in grapes and red wine ${ }^{411,13,42}$. In addition to all these properties, there are studies showing that when used orally they can also be effective in the wound healing process ${ }^{20}$. However, it has been shown that oral administration of resveratrol has low bioavailability and stability in studies performed ${ }^{23,24}$. Loading of nano-molecules to increase the bioavailability of molecules with these properties in the living system has given a different perspective to current treatment approaches ${ }^{25}$. From this approach we aimed to increase resorption and utilization of skin tissue by loading resveratrol into liposomes.

Wound healing models in the literature are generally made using two different models, incisional and excisional (except burn models). We aimed to avoid the use of more experimental animals by forming both incisional and excisional wound tissue in the modified experimental model. In the excisional wound model, the wound tissue surface healing
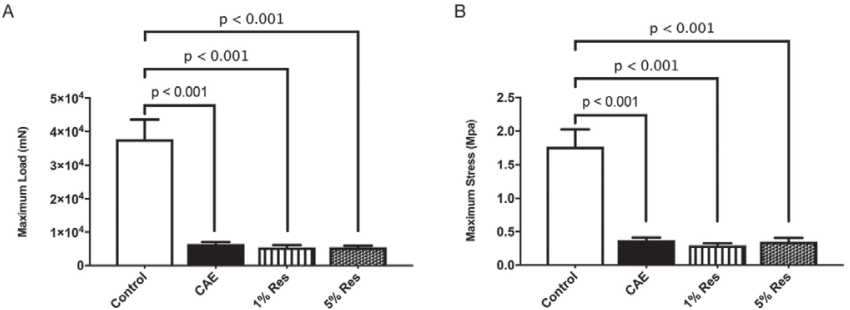

C
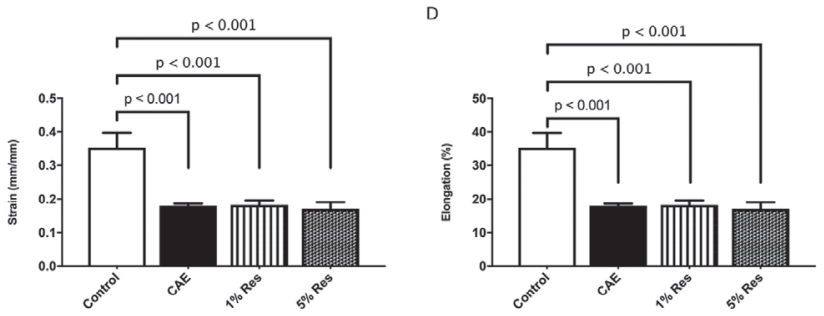

\begin{tabular}{|l|l|l|l|l|}
\hline Max load $(\mathrm{mN})$ & $37675.413 \pm 6012.723$ & $6463.810 \pm 602.290$ & $5471.470 \pm 678.531$ & $5534.906 \pm 447.732$ \\
\hline Max stres (Mpa) & $1.734 \pm 0.257$ & $0.376 \pm 0.037$ & $0.298 \pm 0.033$ & $0.355 \pm 0.054$ \\
\hline Strain $(\mathrm{mm} / \mathrm{mm})$ & $0.353 \pm 0.044$ & $0.179 \pm 0.006$ & $0.182 \pm 0.014$ & $0.171 \pm 0.020$ \\
\hline Elongation (\%) & $35.346 \pm 4.392$ & $17.928 \pm 0.640$ & $18.206 \pm 1.385$ & $17.055 \pm 1.996$ \\
\hline *All values are given as mean \pm S.E.M. CAE: Centella asiatica extract &
\end{tabular}

Figure 3. Axial tensile-elongation measurements in incisional wound tissue. A) Maximum load values, B) maximum stres values, C) strain values, D) elongation (\%) values. All values are given as mean \pm S.E.M

rates were assessed using the imageJ program from photographs taken over time.

When the evaluation of the surface of the excisional wound, there was a significant differences on the $4^{\text {th }}$ day, between CAE and the control group, on the $6^{\text {th }}$ day, between the control group and 1\% Res and 5\% Res groups, on the $10^{\text {th }}$ day, between the control group and CAE, 1\% Res and 5\% Res groups, on the $12^{\text {th }}$ day between the control group and CAE and $5 \%$ Res groups (Figure 1). Similar effect levels at $10^{\text {th }}$ and $12^{\text {th }}$ day between the CAE and 5\% Res groups suggested that resveratrol might be more effective in wound healing at this concentration.

Epidermal and dermal regeneration, granulation tissue formation and angiogenesis are the main determinants of wound healing. The formation of regular granulation tissue, with the formation of capillary vessels and fibriblasts, is one of the important criteria in wound healing. During the healing process of the wounds, the granulation tissue acts to protect against infections and epithelial cells migrate to this area ${ }^{43}$. In our study, biopsy specimens extracted from excisional wound tissue were evaluated as described in the literature ${ }^{39}$. Histological evaluation, the size and organization of the granulation tissue, angiogenesis, epidermal and dermal regeneration were better than the control and the CAE group in 1\% Res and 5\% Res groups (Figure 2). Histologically, findings in healing parameters also coincided with the rates of wound tissue healing and photographic findings.

In the primarily closed incision areas, the axial tensile-elongation tests were performed to determine the differences in the intended wound tissue tension forces. No matter how well the skin tissue heals after the injury, the wound stretching force values can never reach the values before they are damaged. In the treatments applied, it is aimed to reach the level of the tension force which is closest to the solid skin 
tissue. Therefore, when we compare control group values with our other study groups, it is expected that the data will be higher in the control group. No statistically significant difference was found between the groups except the control group. Maximum load, maximum stress, strain and \% elongation values that tissues were able to achive were almost similar to those used as the reference molecule (Figure 3). In the case of axial retraction in a developing skin tissue, the closer the recovery of the damaged tissue to the strong skin tissue, the better the healing is. Proliferation of fibroblasts during wound healing is one of the factors affecting wound tensile. Histological evaluation parameters show us that the values obtained as a result of incisional stretching experiments are valuable.

\section{Study Limitation}

Although our study investigated the effects of liposomal formulations at different concentrations of resveratrol using incisional and excisional wound healing modalities, such as cytokines, growth factors, matrix metalloproteinases, known to be effective in the wound healing process, have not been evaluated by methods such as ELISA and RTPSR.

\section{Conclusion}

Liposomal formulations containing $1 \%$ and $5 \%$ resveratrol at wound healing were found to have positive effects on healing process, both in excisional and incisional wound tissues. The study is a preliminary study and verification of the obtained data with molecular methods will enable to obtain data that will shed light on new treatment modalities.

\section{Ethics}

Ethics Committee Approval: Before performing in vivo experiments, ethical clearance approval was obtained from the Local Ethical Committee [istanbul Medipol University, (approval number: 44, date: 07.08.2018)].

Informed Consent: Informed consent is not necessary as it is an animal experiment.

Peer-review: Internally peer-reviewed.

\section{Authorship Contributions}

Concept: M.Y.G., Ü.K., Design: M.Y.G., Ü.K., Data Collection or Processing: M.Y.G., Ş.A., I.A., N.B., M.Ç.B., A.B.Ç., E.M.Ö., E.Y., Analysis or Interpretation: M.Y.G., Ş.A., N.B., M.Ç.B., A.B.Ç., I.A., E.Y., Writing: M.Y.G.

Conflict of Interest: No conflict of interest was declared by the authors.

Financial Disclosure: The authors declared that this study received no financial support.

\section{References}

1. Singer AJ, Clark RA: Cutaneous wound healing. N Engl J Med 1999;341:738-46.

2. Budovsky A, Yarmolinsky L, Ben-Shabat S: Effect of medicinal plants on wound healing. Wound Repair Regen 2015;23:171-83.

3. Fremont L: Biological effects of resveratrol. Life Sci 2000;66:663-73.

4. Cakmak GK, Irkorucu O, Ucan BH, et al: The effects of resveratrol on the healing of left colonic anastomosis. J Invest Surg 2009;22:353-61.

5. Cai YJ, Wei QY, Fang JG, et al: The 3,4-dihydroxyl groups are important for trans-resveratrol analogs to exhibit enhanced antioxidant and apoptotic activities. Anticancer Res 2004;24:999-1002.
6. Colin D, Lancon A, Delmas $D$, et al: Antiproliferative activities of resveratrol and related compounds in human hepatocyte derived HepG2 cells are associated with biochemical cell disturbance revealed by fluorescence analyses. Biochimie 2008;90:1674-84.

7. Wadsworth TL, Koop DR: Effects of the wine polyphenolics quercetin and resveratrol on pro-inflammatory cytokine expression in RAW 264.7 macrophages. Biochem Pharmacol 1999;57:941-9.

8. Wang G, Hu Z, Fu Q, et al: Resveratrol mitigates lipopolysaccharide-mediated acute inflammation in rats by inhibiting the TLR4/NF-kappaBp65/MAPKs signaling cascade. Sci Rep 2017;7:45006.

9. Jiang L, Zhang L, Kang K, et al: Resveratrol ameliorates LPS-induced acute lung injury via NLRP3 inflammasome modulation. Biomed Pharmacother 2016;84:130-8.

10. Hori YS, Kuno A, Hosoda R, et al: Regulation of FOXOs and p53 by SIRT1 modulators under oxidative stress. PLoS One 2013:8:e73875.

11. Horio $Y$, Hayashi T, Kuno A, et al: Cellular and molecular effects of sirtuins in health and disease. Clin Sci (Lond) 2011;121:191-203.

12. Zhang C, Li Q, Kang L, et al: [Resveratrol inhibits hyperxia-induced cell apoptosis through up-regulating SIRT1 expression in HPAECs]. Xi Bao Yu Fen Zi Mian Yi Xue Za Zhi 2015;31:590-5.

13. Ray PS, Maulik G, Cordis GA, et al: The red wine antioxidant resveratrol protects isolated rat hearts from ischemia reperfusion injury. Free Radic Biol Med 1999;27:160-9.

14. Hao $Y$, Huang $W$, Liao $M$, et al: The inhibition of resveratrol to human skin squamous cell carcinoma A431 xenografts in nude mice. Fitoterapia 2013;86:84-91.

15. Provinciali M, Re F, Donnini A, et al: Effect of resveratrol on the development of spontaneous mammary tumors in HER-2/neu transgenic mice. Int J Cancer 2005;115:36-45.

16. Ganapathy S, Chen Q, Singh KP, et al: Resveratrol enhances antitumor activity of TRAIL in prostate cancer xenografts through activation of FOXO transcription factor. PLoS One 2010;5:e15627.

17. Kimura Y, Okuda H: Resveratrol isolated from Polygonum cuspidatum root prevents tumor growth and metastasis to lung and tumor-induced neovascularization in Lewis lung carcinoma-bearing mice. J Nutr 2001;131:1844-9.

18. Huderson AC, Myers JN, Niaz MS, et al: Chemoprevention of benzo(a) pyrene-induced colon polyps in ApcMin mice by resveratrol. J Nutr Biochem 2013;24:713-24

19. Liu HS, Pan CE, Yang W, et al: Antitumor and immunomodulatory activity of resveratrol on experimentally implanted tumor of $\mathrm{H} 22$ in Balb/c mice. World J Gastroenterol 2003;9:1474-6.

20. Yaman I, Derici H, Kara C, et al: Effects of resveratrol on incisional wound healing in rats. Surg Today 2013; 43:1433-8.

21. Tang ZM, Zhai XX, Ding JC: Expression of $m T O R / 70 S 6 K$ signaling pathway in pathological scar fibroblasts and the effects of resveratrol intervention. Mol Med Rep 2017; 15:2546-50.

22. Ethemoglu MS, Seker FB, Akkaya $H$, et al: Anticonvulsant activity of resveratrol-loaded liposomes in vivo. Neuroscience 2017;357:12-9.

23. Zu Y, Overby H, Ren G, et al: Resveratrol liposomes and lipid nanocarriers: Comparison of characteristics and inducing browning of white adipocytes. Colloids Surf B Biointerfaces 2018;164:414-23.

24. Walle T, Hsieh F, DeLegge MH, et al: High absorption but very low bioavailability of oral resveratrol in humans. Drug Metab Dispos 2004;32:1377-82.

25. Bonechi C, Martini S, Ciani L, et al: Using liposomes as carriers for polyphenolic compounds: the case of trans-resveratrol. PLoS One 2012;7:e41438.

26. Carita AC, Eloy JO, Chorilli M, et al: Recent advances and perspectives in liposomes for cutaneous drug delivery. Curr Med Chem 2018;25:606-35.

27. Aslan I: Studies on liposome, gel and lipogelosome formulations containing sodium hyaluronate. Faculty of Pharmacy, Institute of Health Sciences, Cosmetology: Yeditepe University; 2010.

28. Duman G, Aslan I, Ozer AY, et al: Liposome, gel and lipogelosome formulations containing sodium hyaluronate. J Liposome Res 2014;24:25969.

29. Pierre EJ, Perez-Polo JR, Mitchell AT, et al: Insulin-like growth factor-l liposomal gene transfer and systemic growth hormone stimulate wound healing. I Burn Care Rehabil 1997;18:287-91. 
30. Spies M, Nesic O, Barrow RE, et al: Liposomal IGF-1 gene transfer modulates pro- and anti-inflammatory cytokine mRNA expression in the burn wound. Gene Ther 2001:8:1409-15.

31. Yao $\mathrm{CH}$, Yeh JY, Chen YS, et al: Wound-healing effect of electrospun gelatin nanofibres containing Centella asiatica extract in a rat model. J Tissue Eng Regen Med 2017;11:905-15.

32. Remache D, Caliez M, Gratton M, et al: The effects of cyclic tensile and stressrelaxation tests on porcine skin. J Mech Behav Biomed Mater 2018;77:242 9.

33. Desai $P$, Patlolla RR, Singh M: Interaction of nanoparticles and cellpenetrating peptides with skin for transdermal drug delivery. Mol Membr Biol 2010;27:247-59.

34. Schramlova J, Blazek K, Bartackova M, et al: Electron microscopic demonstration of the penetration of liposomes through skin. Folia Biol (Praha) 1997;43:165-9.

35. Pham TT, Jaafar-Maalej $C$, Charcosset $C$, et al: Liposome and niosome preparation using a membrane contactor for scale-up. Colloids Surf B Biointerfaces 2012;94:15-21.

36. Gunal MY, Heper AO, Zaloglu N: The effects of topical carvacrol application on wound healing process in male rats. Pharmacognosy journal 2014;6:10-
37. Reid RR, Said HK, Mogford JE, et al: The future of wound healing: pursuing surgical models in transgenic and knockout mice. J Am Coll Surg 2004;199:578-85.

38. Okur ME, Ayla S, Cicek Polat $D$, et al: Novel insight into wound healing properties of methanol extract of Capparis ovata Desf. var. palaestina Zohary fruits. J Pharm Pharmacol 2018;70:1407-13.

39. Galeano M, Altavilla $D$, Cucinotta $D$, et al: Recombinant human erythropoietin stimulates angiogenesis and wound healing in the genetically diabetic mouse. Diabetes 2004;53:2509-17.

40. Altavilla D, Saitta A, Cucinotta D, et al: Inhibition of lipid peroxidation restores impaired vascular endothelial growth factor expression and stimulates wound healing and angiogenesis in the genetically diabetic mouse. Diabetes 2001;50:667-74

41. Niwano $Y$, Koga $H$, Sakai $A$, et al: Wound healing effect of malotilate in rats. Arzneimittelforschung 1996;46:450-5.

42. Jang M, Cai L, Udeani GO, et al: Cancer chemopreventive activity of resveratrol, a natural product derived from grapes. Science 1997;275:21820.

43. Somboonwong J, Kankaisre M, Tantisira B, et al: Wound healing activities of different extracts of Centella asiatica in incision and burn wound models: an experimental animal study. BMC Complement Altern Med 2012;12:103. 